E International

\title{
The Evolution of Public Transport Contracts in France
}

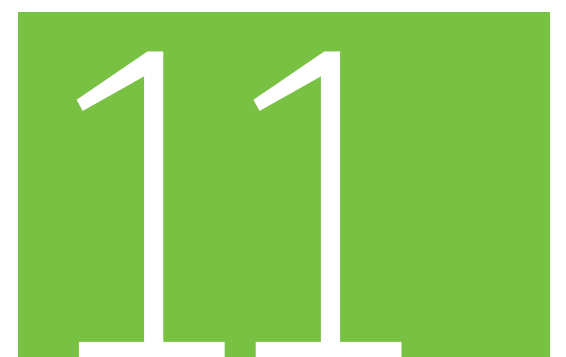

Discussion Paper 2017•11

Odile Heddebaut

Université Paris-Est Marne-la-Vallée, France 


\section{E International Transport Forum}

\section{The evolution of public transport contracts in France}

Discussion Paper No. 2017-11

Prepared for the Working Group on

Public Transport Market Organisation and Innovation

Odile Heddebaut

Université Paris-Est, AME, DEST, IFSTTAR, F-77447 Marne-la-Vallée, France

June 2017 


\title{
The International Transport Forum
}

The International Transport Forum is an intergovernmental organisation with 59 member countries. It acts as a think tank for transport policy and organises the Annual Summit of transport ministers. ITF is the only global body that covers all transport modes. The ITF is politically autonomous and administratively integrated with the OECD.

The ITF works for transport policies that improve peoples' lives. Our mission is to foster a deeper understanding of the role of transport in economic growth, environmental sustainability and social inclusion and to raise the public profile of transport policy.

The ITF organises global dialogue for better transport. We act as a platform for discussion and prenegotiation of policy issues across all transport modes. We analyse trends, share knowledge and promote exchange among transport decision-makers and civil society. The ITF's Annual Summit is the world's largest gathering of transport ministers and the leading global platform for dialogue on transport policy.

The Members of the Forum are: Albania, Armenia, Argentina, Australia, Austria, Azerbaijan, Belarus, Belgium, Bosnia and Herzegovina, Bulgaria, Canada, Chile, China (People's Republic of), Croatia, Czech Republic, Denmark, Estonia, Finland, France, Former Yugoslav Republic of Macedonia, Georgia, Germany, Greece, Hungary, Iceland, India, Ireland, Israel, Italy, Japan, Kazakhstan, Korea, Latvia, Liechtenstein, Lithuania, Luxembourg, Malta, Mexico, Republic of Moldova, Montenegro, Morocco, the Netherlands, New Zealand, Norway, Poland, Portugal, Romania, Russian Federation, Serbia, Slovak Republic, Slovenia, Spain, Sweden, Switzerland, Turkey, Ukraine, the United Arab Emirates, the United Kingdom and the United States.

\author{
International Transport Forum \\ 2 rue André Pascal \\ F-75775 Paris Cedex 16 \\ contact@itf-oecd.org \\ www.itf-oecd.org
}

\section{ITF Discussion Papers}

ITF Discussion Papers make economic research, commissioned or carried out in-house at ITF, available to researchers and practitioners. They describe preliminary results or research in progress by the author(s) and are published to stimulate discussion on a broad range of issues on which the ITF works. Any findings, interpretations and conclusions expressed herein are those of the authors and do not necessarily reflect the views of the International Transport Forum or the OECD. Neither the OECD, ITF nor the authors guarantee the accuracy of any data or other information contained in this publication and accept no responsibility whatsoever for any consequence of their use. This document and any map included herein are without prejudice to the status of or sovereignty over any territory, to the delimitation of international frontiers and boundaries and to the name of any territory, city or area. Comments on Discussion Papers are welcome. 


\begin{abstract}
This paper presents the evolution of public transport contracts in France and the historical and legal contexts which led to their reorganisation. We first examine the evolution of the territorial distribution of institutional powers in transportation mainly for passengers. A focus is made on the regional passenger railway reform in France that allowed the 20 French metropolitan regions to become transport organising authorities following a first experiment by seven volunteer regions. The Nord-Pas de Calais region is taken as an example. Then the urban public transport contracts are analysed focussing on different possibilities of contract and finally, the specific case of transport organisation in the Paris Île de France region is studied.
\end{abstract}




\section{Table of Contents}

Territorial powers to organise transport in France .......................................................................... 5

Regional passenger railway reform .................................................................................................... 6

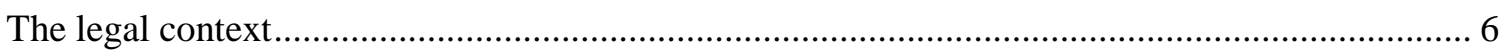

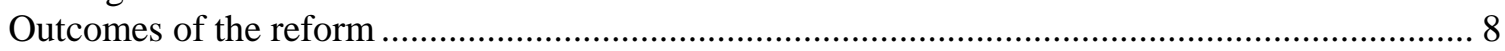

Case 1: The TER in the Nord-Pas de Calais Region ...........................................................9

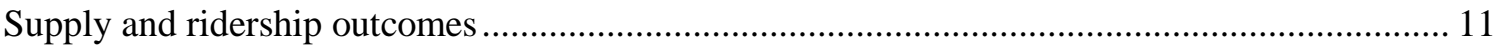

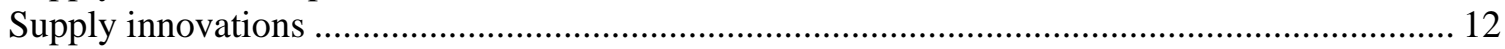

Urban public transport contracts .......................................................................................................... 12

Operation of public transport services: Public Service Delegation (PSD) ................................... 13

Operation of public transport services: Self operation (La régie) ................................................. 14

Case 2: The Paris Île de France region ................................................................................... 16

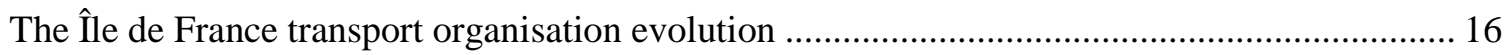

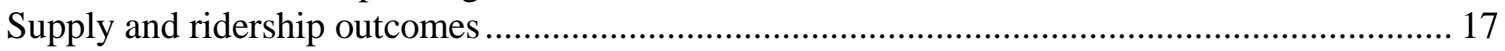

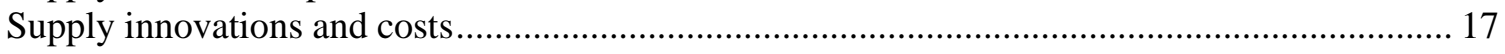

References ……........................................................................................................................................................... 18

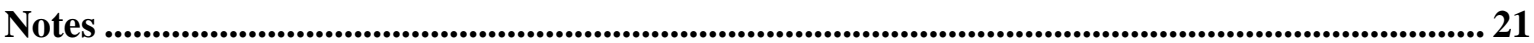


This paper presents the evolution of public transport contracts in France and the historical and legal contexts which led to their reorganisation. In France, before 1937, several private rail companies existed (such as Compagnie du Nord, Compagnie Paris-Lyon-Mediterrannée, Compagnie du Midi and Compagnie de l'Est). As in many other developed countries, several industries were nationalised during and after the world wars, including transport services and infrastructure. This nationalisation was motivated primarily by a need to reconstruct and modernise the economy (Chabanas and Vergeau, 1996). Only in recent decades have steps been taken to move away from this nationalised approach to transport by an attempt to separate transport planning from the railroad network infrastructure owners and the passenger service operators, even if these bodies are still publicly owned.

In this paper we first examine the evolution of the territorial distribution of institutional powers in passenger transport in France. Secondly we analyse the railway reform that allowed the 20 French metropolitan regions to become transport organising authorities following a first experiment by seven volunteer regions. The Nord-Pas de Calais region is explored as an example. Thirdly the urban public transport contracts are analysed and finally, the specific case of transport organisation in the Paris Île de France region is studied.

\section{Territorial powers to organise transport in France}

The Internal Transports Orientation Act (LOTI) of December 1982 (as amended by the Transport Code of 2010) sets out the organisational responsibilities for public transport (PT) services in France. In broad terms:

- The State (national government) is responsible for national and international rail transport (TGV, Eurostar, Thalys) and interregional passenger services. It has also driven the planning and procurement of new urban public transport systems such as tramways, tram-trains and buses with a high level of service. This involvement is in part due to the Grenelle laws 1 and 2 (3rd August 2009 and 12th July 2010) which form a national commitment to environmental outcomes, particularly for transport where the development of urban PT is emphasised.

- The Regions (they were 22 since their creation in 1956 and reduced to 13 since 2015 in metropolitan ${ }^{1}$ France) are in charge of regional train passenger supply (TER) and interdepartmental coaches (since 1st January 2002). And since the law on the new territorial organisation (NOTRe law) of 7th August 2015, departmental road transport services and school transport has been the responsibility of the Regions. It will nevertheless be possible for the Regions to delegate responsibility for school transportation to departments.

- The Departments (96 in metropolitan France) are in charge for the organisation of public transport by intercity coaches, buses and school buses (Article 29 LOTI) within the departmental territorial limits.

- Organising authorities of the mobility (AOMs, known as 'organising authorities for urban transport' prior to 2014) are a fourth level of governance at the urban agglomeration or Region level. AOMs manage urban public transport supply for all the travel within their urban transport perimeter (PTU). The Law on Air and the Rational Use of Energy (LAURE Act) of 
30th December 1996 obliges the AOMs to produce an urban mobility plan for conurbations of more than 100000 inhabitants to encourage the use of public transport as a means of addressing air pollution problems. AOMs may charge a fee to companies of more than 11 employees within the perimeter of urban transport. This tax can contribute to over $40 \%$ of an AOM's budget. It has contributed to enlarging PTUs and enabled them to achieve greater autonomy for AOMs. Since 2004, the State ceased to fund AOMs for transit projects. But the Grenelle laws have allowed the State to launch tenders for financing the realisation of new urban public transport systems such as tramways, tram-trains, bus with high level of service (BHLS) (Finn et al., 2011) and light rail.

\section{Regional passenger railway reform}

Before 1997, the role of the Regions in passenger rail was generally limited to a financial contribution to the national operator, the SNCF, to offer services and specific fares, including subscriptions for commuters or students subsidised by the Regions. Reforms were introduced from 1997 to give greater planning powers to the Regions, allowing them the ability to directly commission new passenger rail services. ${ }^{2}$

\section{The legal context}

In France, the regionalisation of passenger rail transport proceeded in a broader European context where rail infrastructure was being reorganised and where the role of the regional networks was given increasing attention. Following the pioneering initiative in Sweden in 1988, the trend in Europe has been towards separating the service delivery from the ownership and operation of infrastructure. The division of responsibilities between national and regional levels for rail networks has also evolved. For example, the transfer of functions from the State to a regional level has been progressively implemented in Germany, since 1996. Regional level "Länders" were given powers to become organising authorities for passenger rail transport, among other functions.

In the early 1990s, French regional passenger train services (TER) were planned at a national level by SNCF and partly funded by contributions from regional councils for the purchase of rolling stock and a contribution to the operating deficit (Figure 1). Patronage on TER services had decreased by $12.2 \%$ between 1989 and 1993. At the national and regional government level there was a desire to improve the service offer and performance of the TER network. In 1993 a national Senate report considered options to enhance the regional railway traffic (the "Haenel Report"). The regions also wanted to negotiate the quality of service, which required transparency of train-operating prices and the ability to upgrade rolling stock and/or tracks. For instance, when the Nord-Pas de Calais region wanted to create new routes with new frequencies, new regional train carriages were required. All other regions in a similarly situation would have lacked the political willingness to instigate this, though Nord-Pas de Calais was exceptional in this regard (see Case 1 below). 
Figure 1. Agreement between the Region and SNCF before 1997

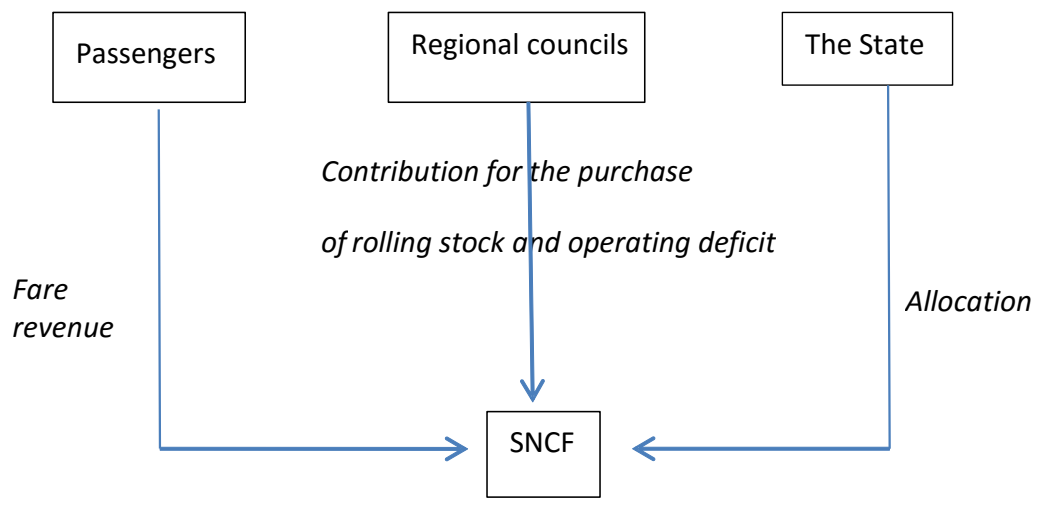

Source: adapted from Decourcelles, 2004

To address these issues, the Guidance law of 1995 on planning and territorial development proposed in its article 67 to experiment with the transfer of regional passengers transport policy powers from the national to the regional level. Between 1997 and 2002 seven Regions volunteered to trial decentralisation of TER planning functions. These seven regions had already adopted their regional transport scheme (SRT) as a planning document fixing all their investments for enhancing the TER services (Varnaison Revolle, 1998). Under the experiment, these Regions were directly allocated funds from the State for the transfer of powers for the organisation and financing of regional rail passenger services (TER). "The first allocation (1997) was established on the basis of an audit carried out by an independent consultancy concerning the service in place at that time. As a result, the State's allocation is reassessed each year, but always for a specific service area." (Decourcelles, 2004, p.10). Consequently the regions assumed the financial risk related to the additional level of service they wanted to offer. Under this arrangement the authority defines consistency, nature (routes, pricing, quality, etc.) and the technical, commercial and qualitative operation of the public service for regional passenger transport. It also it finances this service and makes the necessary investments (rolling stock and station renovation). Each region oversees the service, while the SNCF is responsible for executing this service and managing business relationships with users (Figure 2). The region also invests in developing and improving transport conditions for users by buying new rolling stock and introducing innovation such as real time information in the trains.

Figure 2. Agreement between the volunteer Regions and SNCF after 1997

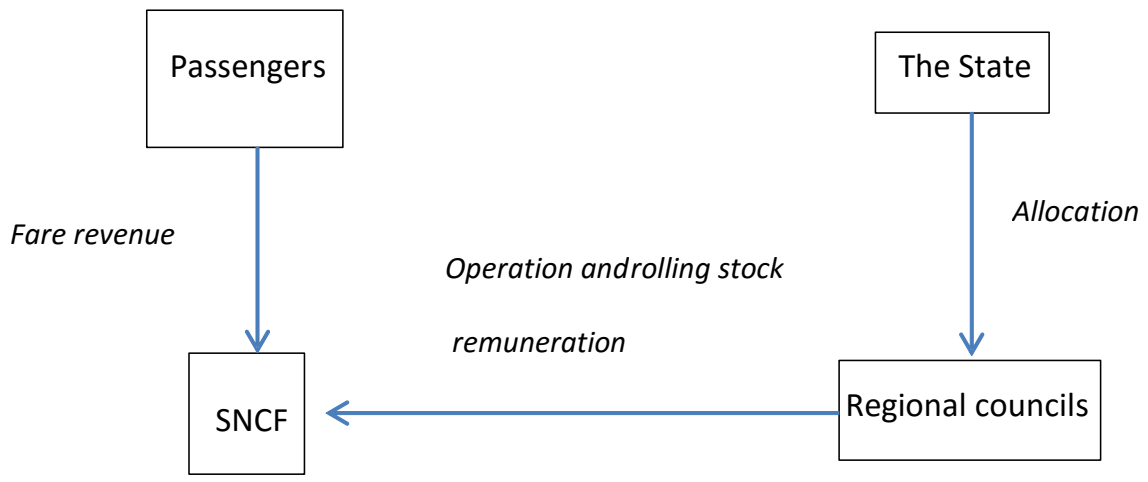

Source: adapted from Decourcelles, 2004 


\section{Outcomes of the reform}

Over the course of the trials, the seven experimenting regions increased the offer, traffic and the patronage compared to other regions (Heddebaut, 2007). Crozet and Desmaris (2011) observe that "the seven testing regions have made a qualitative and quantitative enhancement of their train supply $(+17 \%$ from 1996 to 2000). The result of these efforts was an increase of the ridership of nearly $+22 \%$ and the revenues $+21 \%$ ".

Following the early success with decentralisation, the Solidarity and Urban Regeneration Law (SRU) of 13th December 2000 made all French metropolitan regions (except Île de France and Corse) Organising Authorities for Regional passenger railway transport (beginning 1st of January of 2002). ${ }^{3}$ For the first time the SNCF had become subject to an incentive system with rewards and penalties based on performance criteria such as the regularity of the trains, the quality of service. Regional governments now sign agreements with SNCF Mobilités the sole regional passenger rail service supplier. However, governance between the State and regions is not standardised: different regions do not receive the same grants from the State due to differences in investments made before 1997 and the contracts linking them to the operator SNCF are not the same from one region to another (Desmaris, 2004). The Île de France region has subsequently become a transport authority by entering into the STIF (Syndicat des Transports d'Île de France) as described below.

Once all regions became AOMs, the overall TER traffic increased by 5.4\% between 2002 and 2008, compared to just $3.9 \%$ in the previous five years when only seven of the 20 regions were designated AOMs (Crozet, Desmaris, 2011)."From the point of view of the users, the decentralisation of the competence of organisation of the activity TER has been largely beneficial. By defining an offer, both quantitative and qualitative, better suited to regional needs, it has made the TER more attractive, which is reflected in the strong increases in traffic observed in all regions. The introduction of new tariff policies and greater attention to quality of service has also contributed to this new attractiveness." (Cour des comptes, 2009, p.32).

The problem is that the state has only allocated the regions subsidies based SNCF's 1997 service rather than the updated services that regions have introduced under the decentralisation. Costs for regions include the repayment of the investments SNCF has made in the network (new tracks), rolling stock (new trains) and station regeneration. During the period 2002-2007, SNCF renewed its TER rolling stock by purchasing new equipment, modernising and converting part of its existing fleet, including by heavy revisions financed through the regions. This implies that the regions have to bear significantly higher costs for the amount of subsidies they receive.

Rail regionalisation was an opportunity for SNCF to undergo a kind of cultural revolution. It was required to adapt its regional transport offering under technical production constraints, but also to respond to the needs of stakeholder territories. Several elected officials paid tribute to the ability of the railway staff who agreed to "play the game" and challenge many traditional habits (Haenel, 2008, p. 10).

"The regions have really made the most of this new ability as a tool of local governance. The results are clear: by 2008, the TER carried 700000 passengers a day on one of the 5700 trains on the 260 TER lines of the national network. Traffic growth started as early as 1997-1998, but it intensified for the first time in 2002 with the effects of the first experiments of regionalisation and then more markedly since 2004. Over the period 2002-2007, TER traffic increased by $27 \%$ and revenues by $38 \%$. These good results are the result of major investments, notably in rolling stock, attractive pricing and expanded services adapted to customers' travel needs" (Haenel, 2008 p. 91). 


\section{Case 1: The TER in the Nord-Pas de Calais Region}

The Region of Nord-Pas de Calais, in northern France, was the first to directly contract with SNCF in March 1978 in order to increase the train supply. It also obtained a conditional grant from the State subject to ridership increasing by $12 \%$ by 1984 . The region created the regional collective transport (TCR, an earlier version of TER) in October 1978. The TCR was the first initiative to plan and implement rail transport at the regional level, deriving from the very ambitious and innovative transport plan for the region (SRT). Under the TCR agreement, the region acquired new carriages and SNCF operated these carriages on 10 rail lines. The region succeeded in pushing SNCF to enhance the service and provide further supply on these lines. SNCF was still responsible for deciding on the nature of the service and investments that were subsidised by the region. Progressively the network reached 13 lines (Figure 3). It lasted from 1978 to 1986, then replaced by the TER Nord-Pas de Calais that was created following the new SNCF commercial strategy under the LOTI law of 1982 and further decentralisation provisions.

Figure 3. The TER network in the Région Nord-Pas de Calais

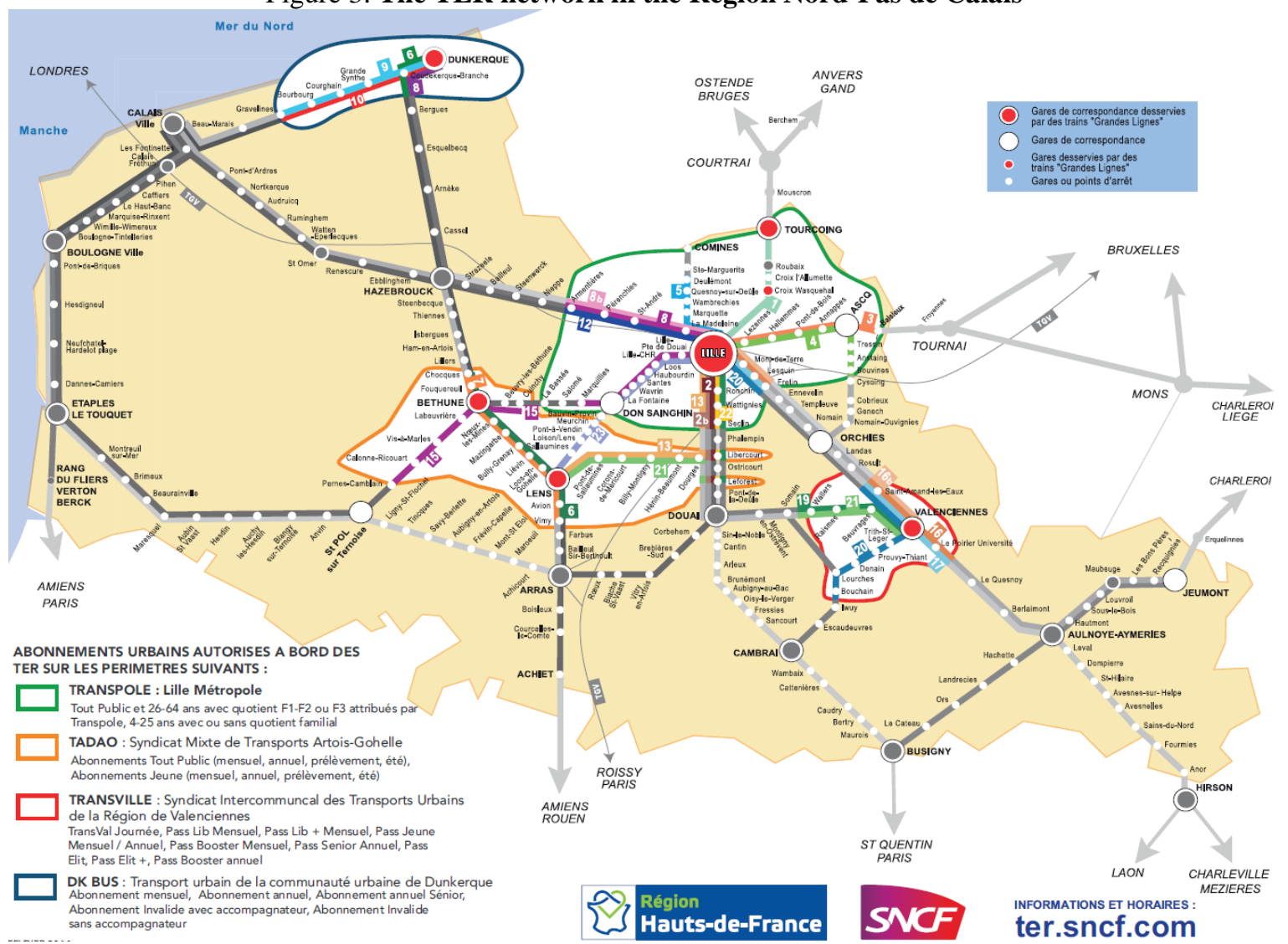

Source: Région Nord-Pas de Calais, SNCF, February 2016

Given its early involvement in decentralisation, it is not surprising that the Nord-Pas de Calais Region was also one of the seven volunteers for the experiment described in the previous section. Under this arrangement between 1997 and 2002, the State grant for the operation grew much slower (7.9\%) than total operating expenses (26.2\%), with the Region contributing an increasing amount to rail services. This is mainly due to the development of the offer in the Region, which was not compensated 
by the State (Decourcelles, 2004 p. 12). This experimental approach was formalised in 2002, when the region became a transport organising authority (AOM) for the TER with both the powers and funding (internal and State contributions) to determine the services and pricing in place on the network.

The strategic transport priorities of the Nord-Pas de Calais are set out in the Regional Scheme for Transport and Mobility (SRTM) of October 2013. It is not a programming document but reflects a strategic vision towards 2030. It aims to build and sustain an efficient regional transport system answering people's and regional actors' needs (especially businesses). The primary objective for the region set out in the SRMT is "to optimise networks and existing equipment and to promote complementarity between the transport modes and cooperation between operators by providing, when necessary, the creation of new infrastructure" (SRTM, 2013, p.15).

The regional rail aspect of the SRTM is then implemented in the 2015-2024 contract agreement between the Nord-Pas-de-Calais Regional council and SNCF Mobilités. The contract states that "SNCF Mobilités should operate interregional, trans-border, TER trains including TER-GV (high speed regional trains running on the high speed tracks) and the railway stations and stopping points. SNCF Mobilités operates coaches linking railway stations in cities with few passengers on the line, including provision, maintenance and equipment maintenance. It must ensure the management services provided at stations, breakpoints and trains or remotely (reception, distribution and validation of tickets), the management of information for travellers and commercial communication TER, the implementation of regional pricing, accessibility for people with reduced mobility, management of prevention and safety, monitoring of quality of service, participation in the development of intermodal transport" (SRTM, 2013, p. 16-17).

This new contract fixes the level of offer and quality of service that SNCF Mobilités must provide. If there is discrepancy between the level required and the service offered, the SNCF is bound by a reward/penalty system. Specifically, the financial contribution of the region for operating the service is primarily determined by operational expenses and track access charges less the revenues earned on the additional regional services. The Nord-Pas-de-Calais Region contributed EUR 246.7 million to SNCF for the operation of passenger rail services in 2015 (Table 1). The Region also contributed EUR 63.6 million to railway infrastructure investments in 2015 (Prod'Homme, 2015). This demonstrates that even if the Region is not in charge of infrastructure management it contributes to this investment sometimes to enable the enhancement of passenger trains schedules. For instance in Hazebrouck, the Region has paid for the railway bypass for freight trains in order to allow new possibilities of traffic for passenger trains passing through and/or stopping in Hazebrouck.

Table 1. Structure of the financial contribution of the Nord-Pas-de-Calais (2015)

\begin{tabular}{|l|l|}
\hline Payments, of which: & $\mathbf{3 2 3 . 2}$ \\
\hline Operational expenses and track access charges & 314.3 \\
\hline Complementary allocation to SNCF & 2.5 \\
\hline Tariff compensations & 5.3 \\
\hline VAT on tariff compensations & 1.1 \\
\hline Receipts, of which: & $\mathbf{7 6 . 2}$ \\
\hline Direct and indirect farebox revenue & 72.5 \\
\hline SNCF compensation for tariff integration between different transport authorities & 2.3 \\
\hline SNCF compensation for running TGV services on part of the regional network & 1.4 \\
\hline Balance paid by Nord Pas de Calais to SNCF & $\mathbf{2 4 7}$ \\
\hline
\end{tabular}

Source: adapted from the Convention SNCF-Région Nord-Pas de Calais, 2015 


\section{Supply and ridership outcomes}

After the implementation of the railway reform for the Nord-Pas de Calais region, the service quality improved. Before the reform, the offer was 9.6 million train kilometres (1996), and after the reform it grew to 10.3 million train $\mathrm{km}$ in 2002; and to 12.2 million train $\mathrm{km}$ in 2005. This represents an increase of $18 \%$ of the train supply between 2002 and 2005. Before the reform, the Nord-Pas-de-Calais TER traffic was 827 thousand passenger $\mathrm{km}$ in 1996 and after the reform, it was 851 thousand passenger $\mathrm{km}$ in 2002; then 943 thousand passenger $\mathrm{km}$ in 2005 (Figure 4). This represented an increase of 10.4\% compared to 2002. In terms of daily passenger trips, traffic grew from 100000 in 2006 to 120000 in 2014. Between 2002 and 2013, there was an increase of 38\% in regional railway trips. One objective of the 2013 SRTM is to reach 200000 trips per day on the TER network by 2020 (a 50\% increase on 2006).

Figure 4. Passenger traffic on the Region Nord Pas de Calais TER network

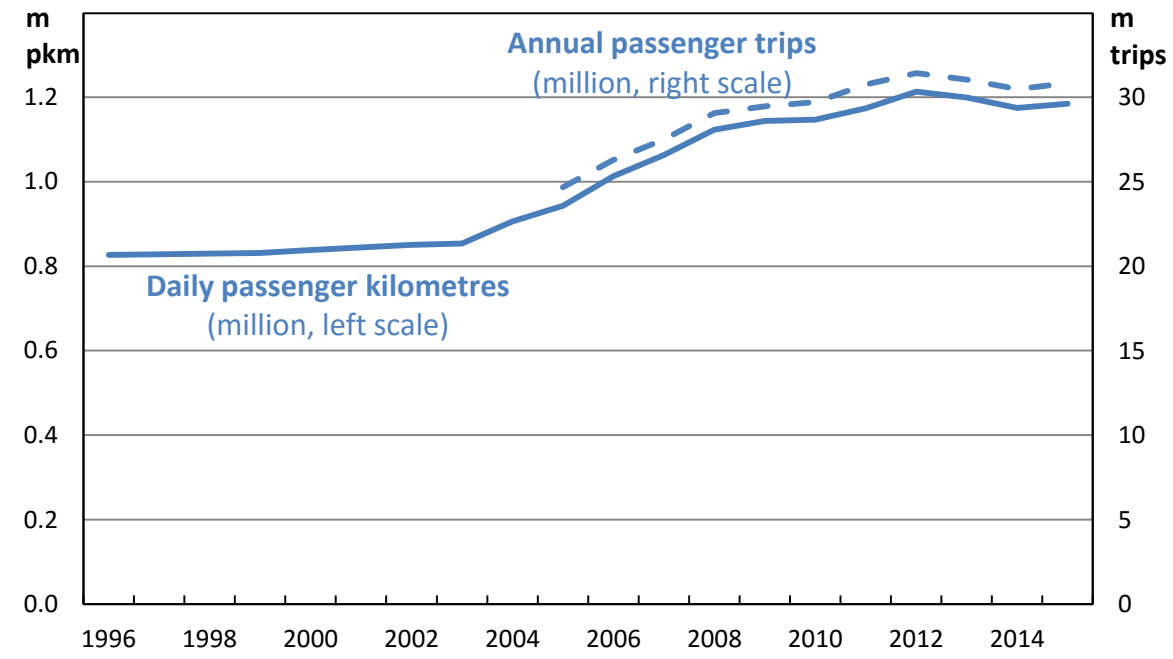

Source: SNCF, Nord-Pas de Calais Region 2017, Heddebaut (2007)

Figure 5. Annual supply on the Nord-Pas de Calais TER network, millions of train kilometres

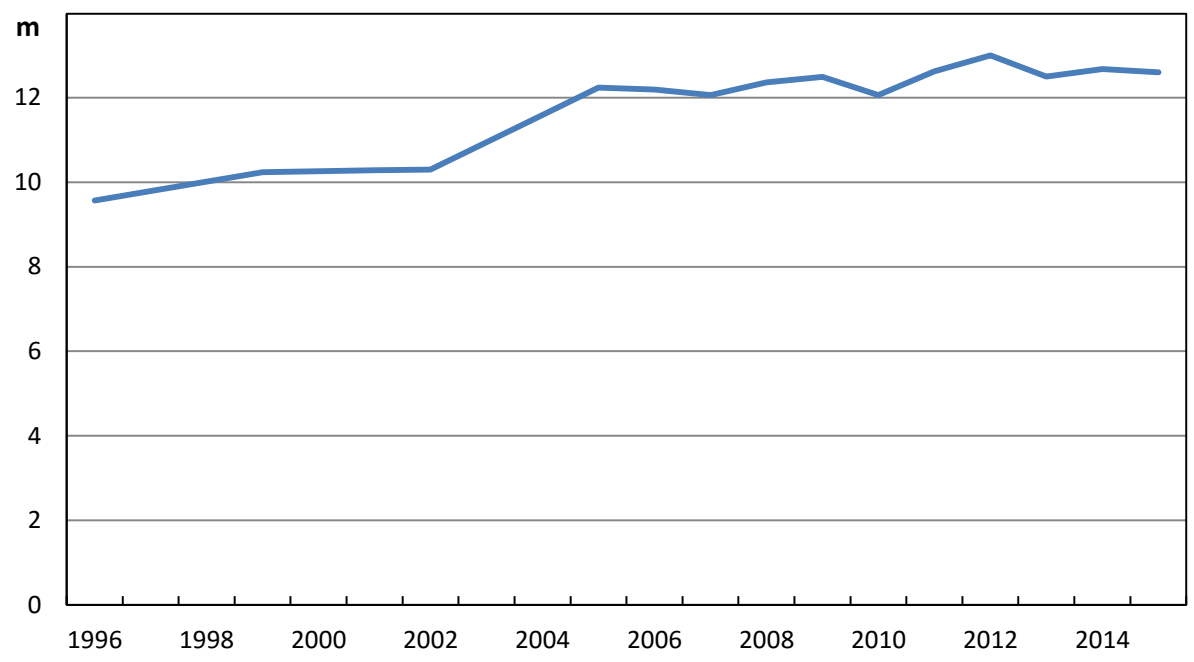

Source: SNCF, Nord-Pas de Calais Region March 2017, Heddebaut (2007) 


\section{Supply innovations}

Innovations introduced in the Nord-Pas de Calais region since the reform include:

- Service - New high speed regional trains ("TERGVs") have operated since 2000. They are regional trains running on the national high speed tracks and are unique in France. Some regional trains now run on high speed tracks within the regional borders as the region rents high speed train carriages from Alstom. The region has paid the network owner (SNCF Réseau) for the electrification of some regional tracks to allow the operation of these TGV trains.

- Participation - The Region created 13 "Comités de lignes" in 2003 that bring together railway passengers, elected members and SNCF staff to discuss performance of the different TER routes.

- Customer information - Since 2012, real time information is provided to customers within the 164 regional railway stations with Navi'TER. The system relays train schedules, itineraries, explanation of delays, trains changes and is available on smartphones, computers through the Internet and Wi-Fi which is unlimited free of charge access within the main railway stations.

- Ticketing and fares - The Pass Pass integrated smartcard for the region was launched in June 2011. It is an initiative launched and administered by the intermodal regional transport syndicate (SMIRT, see below) and accepted on SNCF trains. For the moment it combines the TER tariffs with Lille urban metropolis tariffs (bus, metro, tram, share bikes and share cars) and also in some urban public networks (Dunkirk, Lens Hénin Béthune and Calais) and the Nord departmental network. The Region also created a loyalty card (the Grand'TER card) which offers very low tariffs for specific train journeys, e.g. to the seaside or countryside on some weekends in summer holidays (the card costs EUR 7, trips cost EUR 1 per person and EUR 0.10 for each accompanying person up to 3). These tariffs allow people with limited financial resources to access places they would not have been able to go to in the past.

The decentralisation of State powers to the regions has been complemented more recently by a 2009 law authorising further consolidation of powers at the regional level. Powers of different transport authorities are now able to be brought into a single regional authority allowing the coordination of all the public transport in the region. In December 2009, the Region Nord-Pas de Calais created (and chairs) the SMIRT committee (Syndicat Mixte Intermodal Régional des Transports) that coordinates 14 transport authorities (11 urban transport authorities, 2 departments, and the region) for more seamless public transport within the region.

\section{Urban public transport contracts}

In France, an $\mathrm{AOM}$ is responsible for organising the public transport offer within its urban perimeter. The AOM can be a municipality but more often it represents a conurbation of several municipalities. As of January 2011, there were 296 AOMs and transport networks in France (Allain, 2012a). AOMs are free to choose the delivery model: either directly operating (La régie) or by delegation 
to a third party (Public Service Delegation). Regardless of how services are delivered, the AOMs have a range of responsibilities and funding options that define their activities.

In accordance with the LAURE law (1996), AOMs covering more than 100000 inhabitants must develop an urban mobility plan, conduct a survey of trips and provide multimodal information to travellers. AOMs define a pricing policy that allows access to public transport for economically disadvantaged people and the development of means enabling access to transport for people with reduced mobility. The solidarity and urban renewal law (SRU) in December 2000 requires that AOMs take into account car mobility to facilitate intermodality and integration within the transport network (e.g. consider car parking and urban freight delivery needs). Moreover, in application of the 11th February 2005 law $^{4}$ the AOM must develop an accessibility plan that sets out an approach to providing universal access to public establishments.

AOMs can decide how they fund transport services, including the possibility of establishing a dedicated transport tax (versement transport, VT). The VT is imposed on all employers of more than eleven employees in the urban transport perimeter and its rate is capped by law (Allain, 2012-a). In 2010, excluding the region Île de France, the funding (operating and capital) of urban transport was provided by:

- Employers through the VT (44\%)

- Local communities through tax (28\%) and loans (8\%)

- Travellers through fare revenues $(16 \%)$

- $\quad$ State (1\%) and other (3\%) (Allain, 2012-a).

\section{Operation of public transport services: Public Service Delegation (PSD)}

Most public transport services in France are delivered via third parties through public service delegations (PSDs). In 2010, PSDs represented $91 \%$ of the urban public transport contracts for delivering services of which $9 \%$ were attributed with the procedure of "public market". 82\% of PSDs are granted through calls for tender (GART, 2011). The Sapin Act (1993) aims to prevent corruption and improve transparency in public procedures such that PSDs must ensure:

- Investment and operating costs of the delegated service are fully transferred

- The management environment provides greater efficiency incentive than in the public sphere

- There is the possibility of having a global offer where design, construction and operation are integrated and optimised in order to reduce transaction costs for the public authority (ENA, 2009)

- Contracts are suitably advertised, and that the duration of agreements is limited (tacit renewal is not authorised)

- Regular competition occurs between operators on the award of exclusive operation and temporary limited service rights

- External controls and penalties are in place

- Public information is provided. 
The PSD market is relatively stable. For example, "of the 267 calls for tender launched by the AOMs in 2013 over the period 2005-2013, only 25\% have not renewed the PSD of the incumbent delegate. In 2013 this rate is 10\%" (GART, 2015, p. 10). Two companies operate most of the urban public transport PSDs in the regions: Keolis, a subsidiary of SNCF, that operates $28.5 \%$ of the total 304 AOMs networks and represents $48.8 \%$ of trips and Transdev that operates $36.6 \%$ of the networks and represents $27.5 \%$ of passenger trips (GART, 2015).

\section{Operation of public transport services: Self operation (La régie)}

The AOMs have the right to operate public transport services themselves. This kind of operation is called "la régie" and can only occur where the AOM has financial autonomy. In that case transport authority operates the services with its own staff and rolling stock. Revenues and expenses are part of the AOM's budget. The régie can also take the shape of a local public company (société publique locale, SPL), a status that has been created by the law of 28th May 2010.

Some transport authorities have decided to bring some services back in-house that were previously contracted to private operators. Outside the Île de France, the share of self-operation (rather than PSD) has increased from 9\% in 2010 to 13\% in 2013 (GART, 2010 and 2015). For example (Figure 6):

- The city of Marseille that operates its public transport with the Régie Autonome des Transports de Marseille (RTM)

- The city of Belfort with the Régie des Transports du Territoire de Belfort (RTTB)

- Since September 2011, the Eastern Pyrénées Department is the operator of its interurban coaches that were previously operated by a private company named the Catalan transport, a subsidiary of Keolis

- Since September 2012, the transport services of the Tarn Département were transformed into a local public company

- Since September 2013, the Nice Côte d'Azur Metropolis took back in self operation its urban transport services that were operated by Veolia-Transdev since 2004. Keolis was challenging to operate this network considered as the biggest one in France (without counting Île de France).

- In July 2013, the city of Périgueux decided to take direct management through the creation of an industrial and commercial public establishment (EPIC). 
Figure 6. Transport recently transformed into direct management (régie)

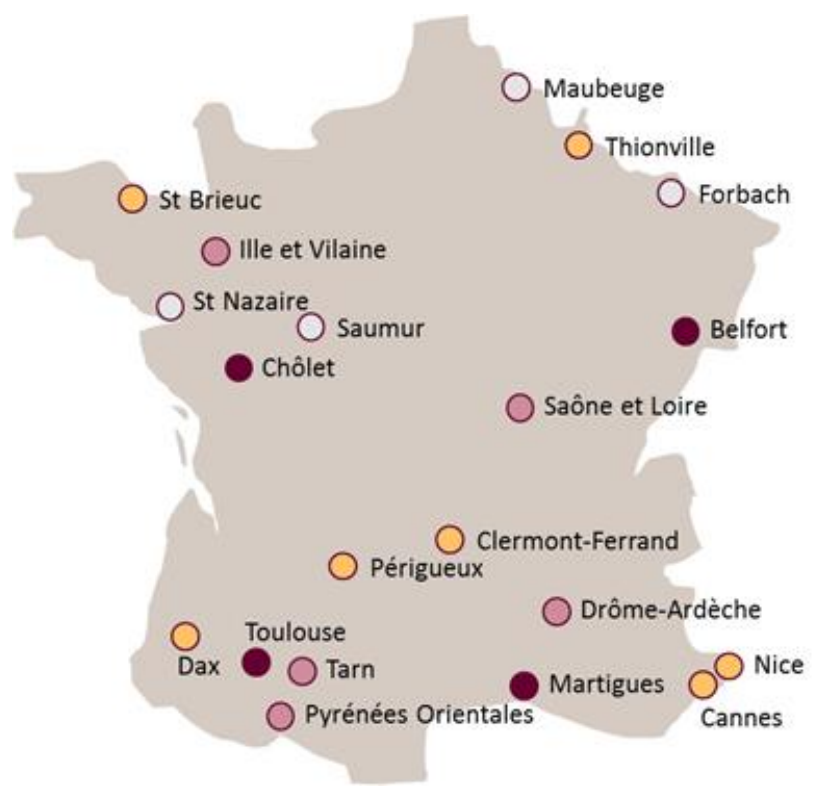

\begin{tabular}{|l|}
\hline Légende: \\
Réseaux urbains en \\
gestion directe depuis \\
les années 2000 \\
Réseaux interurbains en \\
gestion directe depuis \\
2010 \\
Réseaux urbains passés \\
en gestion directe entre \\
2010 et 2012 \\
Réseaux urbains passés \\
en gestion directe \\
depuis 2012
\end{tabular}

Source : Transport et Distribution, Sia Partners (2014)

Some explanations may be given by the table below showing the advantages of the "régie directe" even if it still remains a small share in the PT contracts.

Table 2. Operational and financial comparative advantages of public transportation management modes

\begin{tabular}{|c|c|c|}
\hline & Self management (Régie) & Public Service Delegation \\
\hline $\begin{array}{l}0 \\
p \\
e \\
\mathrm{r} \\
\mathrm{a} \\
\mathrm{t} \\
\mathrm{i} \\
\mathrm{o} \\
\mathrm{n} \\
\mathrm{a} \\
\mathrm{I}\end{array}$ & $\begin{array}{l}\text { - Simplicity of implementation (tender } \\
\text { exemption) } \\
\text { - The local municipality keeps the mastery on } \\
\text { the activity (less true in the case of } \\
\text { individualised self-operation) } \\
\text { - Prioritisation of development axis and } \\
\text { alignment of service on the municipal } \\
\text { strategy } \\
\text { - The fields of action are extended in the } \\
\text { case of individualised self-operation } \\
\text { (possibility to participate in the private } \\
\text { sector) } \\
\text { - No contractual obligations or constraints. }\end{array}$ & $\begin{array}{l}\text { - } \text { Clearer and transparent award } \\
\text { procedures (code of public } \\
\text { procurement, tendering) } \\
\text { - Ability to assign objectives to the } \\
\text { delegate and sanctions in case of } \\
\text { breach. } \\
\text { - Risk management taken by the } \\
\text { delegate. } \\
\text { - Greater operational flexibility and } \\
\text { faster adaptation to changes (no } \\
\text { administrative slowness) } \\
\text { - Capitalising on expertise and best } \\
\text { practices through multi networks } \\
\text { private actors. }\end{array}$ \\
\hline $\begin{array}{l}\mathbf{F} \\
\mathbf{i} \\
\mathrm{n} \\
\mathrm{a} \\
\mathrm{n} \\
\mathrm{c} \\
\mathrm{i} \\
\mathrm{a} \\
\mathrm{I}\end{array}$ & $\begin{array}{l}\text { - Funding Guarantee } \\
\text { - Possession of assets and management } \\
\text { skills: no loss of assets and expertise } \\
\text { potential as can be the case when renewing } \\
\text { PSD } \\
\text { - Fiscal advantages : } \\
\text { - The communities do not have to apply VAT } \\
\text { on capital expenditures (related to transport } \\
\text { tax) while maintaining the ability to recover } \\
\text { all the VAT paid. } \\
\text { - Direct operation, in most cases, are not } \\
\text { subject to corporation tax, the fixed annual } \\
\text { tax and local business tax. }\end{array}$ & $\begin{array}{l}\text { - The financial risk of the operation is } \\
\text { supported by the delegate (including } \\
\text { investment) } \\
\text { - Pricing is based on the operating result } \\
\text { and promotes rigorous financial } \\
\text { management } \\
\text { - Financial transparency, costs that } \\
\text { cannot be diluted in the community's } \\
\text { accounting } \\
\text { - Financial stability of the delegate } \\
\text { through the establishment of stable } \\
\text { multi-year financing plans. }\end{array}$ \\
\hline
\end{tabular}

Source : Transport et Distribution, Sia Partners (2014) 


\section{Case 2: The Paris Île de France region}

The Île de France Region was created in 1976 and covers an area of $12000 \mathrm{~km}^{2}$, including 1300 cities and 11.8 million inhabitants. At its centre is the City of Paris ( 2.2 million inhabitants), surrounded by the first belt cities ( 3 départements and 123 cities and 4.5 million inhabitants) and the second belt (4 départements, 1157 cities and 5 million inhabitants). The transport modes covered are the Regional Express Rail passengers Trains (RER), Metro, tramway, buses, and self-service bikes.

\section{The Île de France transport organisation evolution}

From 2000, control of public transport in Île de France progressively shifted from the State to the region. Before 2001 passenger transport was under the jurisdiction of the Parisian Transport Syndicate (STP) chaired by the préfet (the State's highest representative in the region). Since December 2000 (law SRU), the STP was replaced as AOM by the Île de France Transport Syndicat (STIF) and the Regional council entered into its Administration council. The 2004 decentralisation law obliged the State to leave the administration council of the STIF.

Since the 8th December 2009 law on organisation and regulation of rail transport, the STIF organises, coordinates and funds public passenger transport. In future years, the STIF has proposed that it will gradually open its public transport markets to new competitors; bus services in 2024, tramway services in 2029 and RER and metro in 2039. Currently transport services are operated by direct award to government bodies. Specifically:

1. The RATP (created by the 21st March 1948 law) is the main operator of the Region, receiving $51 \%$ of the resources allocated by the STIF in 2014. It has a monopoly over metro, tram and bus services in the city of Paris for an unlimited period. It operates 16 metro lines, 2 RER train lines, over 350 bus lines and 4 tram lines. In 2010 it carried 3 billion passengers and had a turnover of EUR 4.2 billion.

2. The SNCF is a corporatised national company that, through SNCF Mobilités, is the only operator licensed to provide rail services on French territory, except for international services. In the Île de France region it is the second operator, receiving 33\% of the STIF allocated resources in 2014. In 1999, it created the "Transilien" commercial brand dedicated to the Île de France regional rail network services. Transilien operates all commuter trains (except lines RER A and B which it jointly operates with RATP). In 2012 SNCF services in Île de France carried 2.9 million daily passengers compared to 800000 for the rest of France (Allain, 2012a).

3. OPTILE (Professional Organisation of Transporters of Île de France) brings together all the other carriers operating in Île de France under the STIF authority. The 72 OPTILE operators received 12\% of the STIF allocated resources in 2014. These operators include both family operators and large groups, such as Veolia-Transdev (half the OPTILE turnover) and Keolis. In 2010 OPTILE covered 1082 routes and carried 301.3 million trips.

The STIF maintains the Transport Plan, defines the general conditions for operations and tariff policy. "Its main role is to define the supply of transport and the level of service quality in the context of contracts with different operators to obtain the best use, economically and socially of the corresponding transport system in conditions defined by decree in Council of State" (8th December 2009 law). The 
STIF also handles the transport tax (VT).The VT revenue is around EUR 3 billion per year and represents about $60 \%$ of all operating revenues (Cantet, 2012).

In Île-de-France, the VT rates in percentage of salaries applicable on 1 July 2015 (year of implementation of the single price of the Navigo pass) are:

- $2.85 \%$ in Paris and in the municipalities of the department of Hauts-de-Seine;

- $1.91 \%$ in the municipalities of Seine-Saint-Denis departments, the Val-de-Marne, Seine-etMarne, Yvelines, Essonne and Val-d Oise;

- $1.50 \%$ for other municipalities of Île-de-France.

The STIF is responsible for organising school transport, the transport of mobility-impaired people and public river services. It defines the principles of large infrastructure projects, adopts the rules for their implementation, and provides project management and financing.

In 2011 the State took back a role in the Île de France transport planning by creating the "company of the Greater Paris" (Société du Grand Paris) to oversee new infrastructure in Greater Paris area, notably the Grand Paris Express a proposed major expansion of the Metro network (Allain, 2012a).

The reforms since 2000 have helped to clarify the relationship between the AOM (STIF) and national transport operators. This relationship had previously been marked by the ambiguity around the role of State. The AOM was previously directed by the state, which was at the same time the shareholder of public companies that deliver most services. This earlier situation created conflicts of interest resulting in procedures that did not ensure consistency of the choices made and delivered poor cost control (Cour des Comptes, 2009).

The STIF and the Île de France region are now controlling the offer level and the quality of service with new arm's-length contracts for RATP and SNCF and OPTILE fixing bonuses and penalties based on the level of service quality provided.

\section{Supply and ridership outcomes}

Supply and ridership have increased strongly since the governance reforms. In 2000 the number of trips in RER and commuter trains was 936 million; in the metro 1.25 billion; in the tramway 36 million and in buses in Paris 358 million trips (total of 3.37 billion trips). After the reform, in 2014 the number of trips in RER and commuter trains increased up to 1.21 billion; metro 1.53 billion; tramway 223 million $^{5}$ and buses in Paris 331 million. The total patronage for all modes is now 4.31 billion trips, a $21 \%$ increase in 14 years. Passenger kilometres travelled on the network increased even more strongly, by $32 \%$ (23.4 billion in 2000 to 30.8 billion passenger $\mathrm{kms}$ in 2014). Over this same period, the population in Île de France increased by 9\%, from around 11.0 million to 12.0 million (OMNIL, 2015).

\section{Supply innovations and costs}

The STIF has expanded its service offering since the reforms. Real time information is now provided online and to smartphone applications. Automation of Metro line 1 (the oldest and most crowded line) was completed in December 2012. And there have also been efforts to modernise the ticketing system. A new chip-based ticketing card that is rechargeable by mobile phone (Navigo) has been implemented to replace the paper carte orange.

In 2015 the operation budget of public transport in Île de France region was EUR 9.4 billion (against EUR 5.4 billion in 2000). It is funded from the following sources (OMNIL, 2015): 
- $\quad$ Transport tax (VT): $40 \%$

- Fare revenue: $29 \%$

- Public authorities subsidies: $19 \%$ (including the State, $1.4 \%$ )

- Employers (repayment of subscriptions): 9\%

- others (advertising and fines): $3 \%$

While the overall budget increased by $70 \%$, the contribution of the State decreased from EUR 445 million in 2000 to EUR 128 million in 2015, suggesting a very large increase in funding was required from the Île de France Region itself. The reform led to a substantial increase in ridership and passengers kilometres travelled (respectively +21 and $+32 \%$ ).

Yet, whether the reform is to be considered a success is questionable as over the period operating costs have increased nominally by $70 \%$ (against a $26 \%$ consumer price inflation). Further research into the question would be required to asses in greater detail the outcomes of the reform against its objectives.

\section{References}

Abraham, C., Bourrier, S., (1994), Les concessions de transport public en zone urbaine, rapport intérimaire du groupe de travail du CNT, Conseil National des Transports, 345 p.

Allain, J-P., (1999), "Les grands groupes français de transport de voyageurs : Histoire, stratégies, diversification," CERTU, collection dossiers, n 100, 329 p.

Allain, J-P., (dir), (2012a), "Les transports publics urbains en France : Organisation institutionnelle," CERTU, collection références, n 130, 131 p.

Allain, J-P., (dir), (2012b), "La délégation de service public en transport urbain," CERTU, collection références, n 128, 105 p.

Burlando, C., Guihery, L., (2004), "La régionalisation du transport ferroviaire régional de voyageurs : expériences françaises et italiennes," les Cahiers Scientifiques du Transport, N ${ }^{\circ} 45 / 2004$ - pp. $125-154$

Cantet, F., (2012), Évolution du versement transport en Île de France, Connexions, mars-avril-mai-2012 p.9

Chabanas, N., Vergeau, E., (1996), "Nationalisations et privatisations depuis 50 ans," INSEE Première, $\mathrm{N}^{\circ} 440$, avril.

Convention pour l'exploitation et le financement du service public ferroviaire d'intérêt régional de transport de voyageurs 2015-2024, signée entre Région Nord - Pas-de-Calais et SNCF Mobilités. 
Cour des comptes, (2009), "Le transfert aux régions du transport express régional (TER) : un bilan mitigé et des évolutions à poursuivre," Novembre 2009.

Crozet, Y., Demaris, C., (2011), "Le transport ferroviaire régional de voyageurs : un processus collectif d'apprentissage," Recherche Transports Sécurité (Springer), 27 (3), pp.143-162.

Decourcelles, J-P., (2004), "Bilan socio-économique de la régionalisation du TER en Nord-Pas de Calais," Rapport au Conseil Economique et Social Régional en préparation de la séance plénière du 10 March, $51 \mathrm{p}$.

Demaris, C., (2004) "La régionalisation ferroviaire : architecture conventionnelle et modes de gouvernance", Transport, $\mathrm{N}^{\circ} 424$, mars-avril pp. 104-105.

Émangard, P. H., Collardey, B., Zembry, P., (2002) “Des omnibus aux TER (1949-2002)," La Vie du Rail, novembre, $463 \mathrm{p}$.

Finn, B., Heddebaut, O., Kerkhof, A., Rambaud, F., Sbert Lozano, O., Soulas, C., (2011), "Buses with High Level of Service", Fundamental characterististics and recommendations for decision-making and research Results from 35 European Cities, Final Report COST TU0603, 180 p.

Fort, P., (2015), l'année 2013 des transports urbains, GART, August, 2015, 52 p.,

GART, (2011), l'année 2010 des transports urbains (hors Île de France) sur 175 réseaux, 32 p..

GART, (2013), l'année 2012 des transports urbains, 48 p.

Guernalec, F., (2015), "Passe Navigo unique à partir du 1er septembre 2015," Mobilicités, February 2015.

Haennel H. (1993) "Rapport de la Commission d'enquête chargée d'examiner l'évolution de la situation financière de la SNCF," June, rapport Sénat $N^{\circ} 335$

Haenel, H., (2008), "Des régions à l'Europe : les nouveaux défis du chemin de fer français," Rapport au Premier ministre, La documentation française, collection des rapports officiels, Octobre 2008.

Heddebaut, O., (2002), "La politique de transport ferroviaire régionale de voyageurs : Quelle nature, quelle stratégie(s) et quelle(s) évaluation(s) ?," Actes des 4èmes journées françaises de l'évaluation, Société française de l'Évaluation, "l'évaluation au service de la stratégie publique?", p. 339-360.

Heddebaut, O., (2007), "The French regional passengers railway transport policy for the 7 “experimental" regions", Paper $N^{\circ} 741$, for the ERSA European Regional Science Association and ASRDLF French Language Regional Science Association Conference, Paris Cergy, 29th August - 2nd September 2007, 16 p.

http://transport.sia-partners.com/20140314/vers-un-retour-en-force-de-la-gestion-directe-des-transportspublics-locaux\# accessed 12th October 2015

https://www.nordpasdecalais.fr/jcms/c_5272/les-comites-de-ligne-ter

http://www.omnil.fr/spip.php?article73, accessed 5 January 2017. 
Région Hauts-de-France, (n.d.) "TER : le rôle de la région," available: http://www.nordpasdecalais.fr/jcms/c_5269/ter-le-role-de-la-region, [accessed 1 February 2016].

Loi $\mathrm{n}^{\circ}$ 2005-102 du 11 février 2005 pour l'égalité des droits et des chances, la participation et la citoyenneté des personnes handicapées (1)

Loi $\mathrm{n}^{\circ}$ 2009-1503 du 8 décembre 2009 relative à l'organisation et à la régulation des transports ferroviaires et portant diverses dispositions relatives aux transports

Loi $\mathrm{n}^{\circ}$ 2009-1503 du 8 décembre 2009 relative à l'organisation et à la régulation des transports ferroviaires et portant diverses dispositions relatives aux transports

Loi n 2015-991 du 7 août 2015 portant nouvelle organisation territoriale de la République.

Loi n 92-125 du 6 février 1992 relative à l'administration territoriale de la République

Loi n 93-122 du 29 janvier 1993 relative à la prévention de la corruption et à la transparence de la vie économique et des procédures publiques

OMNIL (Observatoire de la mobilité en Île-de-France) (2015), "Dépenses de fonctionnement pour les dépenses en transport en commun," 25 November 2015.

Prod'Homme, H., (2015) Projet de comparaison des Budgets régionaux Nord-Pas de Calais et Picardie, rapport pour le CESER, 08 septembre 2015, 35 p.

Région Nord-Pas-de-Calais, (2013), "Schéma régional des transports et des mobilités (SRTM)," adopté en séance plénière le 26 September 2013, 115 p.

Revue des transports publics (2012), "Un projet de directive européenne menace la DSP à la française".

Revue Générale des Chemins de Fer, (2004), "La régionalisation du transport de voyageurs," Numéro spécial, January, $140 \mathrm{p}$.

Sia Partners, (2016), "Vers la disparition des tickets de métro ? Le programme francilien de modernisation de la billetique".

Sinaï, A., (2014), « L'eau à Paris : retour vers le public », published by Eau de Paris, May 2014, 159 p.

STIF, (2013) "Modernization of the ticketing system in Île de France by setting up Transport Units," Déliberation $\mathrm{N}^{\circ}$ 2013/008, 13 February 2013, 43 p.

Thomé, B., Bonnet, G., Houles, L., Canet, A., (2001), "La régionalisation des transports ferroviaires," CERTU Université Lumière Lyon II, ENTPE, Avril, 123 p.

Varnaison-Revolle, P., (1998), “Schémas régionaux de transport : avancement des démarches,"March, CERTU, $22 \mathrm{p}$. 


\section{Notes}

Some Regions had already been contracting with SNCF for the delivery of specific scheduled services without having the authority rights (for example the Nord Pas de Calais region since 1978).

The LOTI (modified by law SRU of December 2000) now stipulates in its article 21-1 that "in addition to the regular interurban road services of regional interest, the Region, as an organising authority of collective transport of regional interest, is charged with the organisation of the regional passengers railway services, that are the railway travellers passenger services carried out on the national railway network, except for the services of national interest and of the international services; and road services carried out in substitution of the railway services". Burlando and Guihéry (2004) note that "the Regions will sign specific contracts with SNCF in order to control the efficiency of its services.

ACT No. 2005-102 of 11 February 2005 for equal rights and opportunities, participation and citizenship of people with disabilities

The STIF began operating two new tramways, which explains the increase in patronage. 
